\section{Auxin, carbon dioxide and hydrogen ions}

HYDROGEN ions can partially mimic the effect of indoleacetic acid (IAA) on plant cell elongation ${ }^{1}$. This observation has been elaborated in a proposal that the initial action of IAA causes the activation of a proton pump at the cell membrane. The pumping of protons would cause a lowering of the $p \mathrm{H}$ at the cell wall, leading to wall loosening ${ }^{2}$. This proposal has been supported in studies in which the $p H$ of the medium surrounding oat coleoptile ${ }^{3-5}$ or etiolated pea stem $^{6}$ sections was observed to drop when auxin was applied. This acidification was most pronounced when tissue sections were used from which the epidermis with the cuticle had been peeled off ${ }^{3}$, and was presumed to be caused by the proton pump activated by IAA.

An increase in cell respiration occurs when tissues respond to exogenous IAA (ref. 7). The IAA-induced $p \mathrm{H}$ drop observed in the solutions surrounding peeled tissue sections may be attributable to increased leakage of $\mathrm{CO}_{2}$ from the tissue and subsequent formation of carbonic acid. To investigate this possibility, we measured $\mathrm{CO}_{2}$ concentrations in the solutions surrounding pea epicotyl sections challenged with IAA.

Pea seeds (Pisum sativum L. cv. Alaska, lot 401 from Burpee Seed Co., Riverside, California) were germinated in the dark at room temperature $\left(21^{\circ} \mathrm{C}\right)$. Subapical $10-\mathrm{mm}$ sections from the third internode were cut from 8-d-old seedlings. In peeled section experiments, the epidermis with cuticle was removed with fine forceps ${ }^{3}$. After the experimental period, the section lengths were measured, the $p \mathrm{H}$ of the medium taken, and the $\mathrm{CO}_{2}$ contents of the solutions were measured with a Natelson model 600 microgasometer (Scientific Industries, Springfield, Massachussetts), which manometrically measures $\mathrm{CO}_{2}$ in solutions.

Table 1 Effect of IAA on $p \mathrm{H}$ and $\mathrm{CO}_{2}$ in the solution surrounding etiolated pea stem sections*

\begin{tabular}{lccc}
\hline Conditions & $p \mathrm{H} \pm$ s.d. & $\mathrm{mM} \mathrm{CO}_{2} \pm$ s.d. & $\begin{array}{c}\text { Calculated } \\
p \mathrm{H}\end{array}$ \\
Unpeeled & $6.04 \pm 0.09$ & $1.6 \pm 0.09$ & 6.02 \\
Unpeeled + IAA & $5.81 \pm 0.10$ & $3.8 \pm 0.06$ & 5.73 \\
Peeled & $5.87 \pm 0.08$ & $1.9 \pm 0.09$ & 5.97 \\
Peeled + IAA & $5.45 \pm 0.11$ & $5.3 \pm 0.56$ & 5.45 \\
No sections & $6.30 \pm 0.00$ & $0.5 \pm 0.12$ & 6.15 \\
\hline
\end{tabular}

*Prepared sections were stirred in $200-300 \mathrm{ml} 1.0 \mathrm{mM} \mathrm{KH}_{2} \mathrm{PO}_{4}$ buffer, $p \mathrm{H} 6.25$ for $150-200 \mathrm{~min}$. Rinsed sections were divided into lots of 45 and placed in $50 \mathrm{ml}$ beakers containing $5 \mathrm{ml} 1.0 \mathrm{mM}$ $\mathrm{KH}_{2} \mathrm{PO}_{4}$ buffer, $p \mathrm{H} 6.30$. After $30 \mathrm{~min}$, the initial $p \mathrm{H}$ reading was taken and IAA was added to $10 \mu \mathrm{M}$. Beakers were sealed with Parafilm and allowed to stir for $3 \mathrm{~h}$ at which time readings were taken $^{3}$.

Measurements of $p \mathrm{H}$ showed that IAA induced some acidification in the solution surrounding unpeeled sections, but that the acidification was more pronounced when peeled sections were used (Table 1). These data confirm previous results reported for unpeeled ${ }^{8}$ and peeled ${ }^{3}$ sections. The $\mathrm{CO}_{2}$ measurements showed that when there was a drop in $p \mathrm{H}$, there was also a rise in the $\mathrm{CO}_{2}$ content of the solution. Using a $K_{\mathrm{a}}$ for total $\mathrm{CO}_{2}$ in solution of $4.2 \times 10^{-7}$ and a $p K_{\mathrm{a}}$ for the buffer used of 7,2 we were able to calculate the $p \mathrm{H}$ of the solution expected if only $\mathrm{CO}_{2}$ was involved in the acidification ${ }^{8}$. These calculated $p \mathrm{H}$ values (Table 1 ) are quite similar to the measured $p \mathrm{H}$, indicating that dissolved $\mathrm{CO}_{2}$ was probably responsible for the IAA-induced $p \mathrm{H}$ reduction.

We carried out a time-course experiment to further examine the correlation between dissolved $\mathrm{CO}_{2}$ and reduction in $p \mathrm{H}$. When peeled sections were exposed for varying times to IAA, the results confirmed the correlation between increases in $\mathrm{CO}_{2}$ and decreases in $\mathrm{pH}$ in the surrounding medium. Once again,
Table 2 Time course of $p \mathrm{H}$ and $\mathrm{CO}_{2}$ changes in solution surrounding IAA-treated etiolated pea stem sections

\begin{tabular}{cccc}
\hline Hours in IAA & $p \mathrm{H}$ & $\mathrm{mM} \mathrm{CO}_{2}$ & Calculated $p \mathrm{H}$ \\
0 & 6.1 & 0.5 & 6.15 \\
1 & 5.8 & 3.4 & 5.73 \\
2 & 5.6 & 4.4 & 5.63 \\
3 & 5.3 & 5.8 & 5.43 \\
\hline
\end{tabular}

the $\mathrm{CO}_{2}$ effect was calculated to be adequate to account for the $p \mathrm{H}$ drop observed (Table 2).

To determine the relationship between the two correlated phenomena in solution, we carried out experiments in flasks with $\mathrm{KOH}$-soaked filter paper in a centre well with the sections and solution surrounding the well. As the $\mathrm{KOH}$ would neutralise any $\mathrm{CO}_{2}$-caused acidification, any $\mathrm{pH}$ reduction would then be caused by other phenomena. That little $p \mathrm{H}$ reduction was observed in such an experiment (Table 3 ) suggests a cause and effect relationship between increased $\mathrm{CO}_{2}$ and reduction of $p \mathrm{H}$ during IAA treatment. It has been shown that exogenous $\mathrm{CO}_{2}$ increases can induce cell elongation'. In all of our experiments, cell elongation (approximately $2 \mathrm{~mm}$ in $3 \mathrm{~h}$ ) occurred only in IAA-treated tissue.

Table 3 Effect of $\mathrm{KOH}$-soaked paper in a centre well on $p \mathrm{H}$ and $\mathrm{CO}_{2}$ in solution surrounding etiolated pea stem sections*

\begin{tabular}{llcc}
\hline Conditions & $p \mathrm{H}_{ \pm}$s.d. & $\mathrm{mM} \mathrm{CO}_{2} \pm$ s.d. & Calculated $p \mathrm{H}$ \\
Unpeeled & 6.15 & 1.2 & 6.06 \\
Unpeeled+IAA & $6.11 \pm 0.09$ & $1.1 \pm 0.08$ & 6.07 \\
Peeled & 6.15 & 1.4 & 6.04 \\
Peeled+IAA & $6.09 \pm 0.10$ & $1.3 \pm 0.09$ & 6.04 \\
\hline
\end{tabular}

*Sections were treated as described in Table 1, except that the experiment was run in a flask with a centre well, containing filter paper soaked with $10 \% \mathrm{KOH}$ or water (control).

The source of the increased $\mathrm{CO}_{2}$ in our experiments is probably increased cell respiration induced by IAA, the gas dissolving to form carbonic acid, which dissociates into bicarbonate and hydrogen ions. Plant cuticles are generally impervious to $\mathrm{CO}_{2}$, and consequently the $p \mathrm{H}$ drop in the solution would be expected to be more pronounced in peeled than unpeeled section experiments ${ }^{10}$.

Our data tend to negate the hypothesis that the $p \mathrm{H}$ drop observed in the solutions surrounding IAA-treated tissue is attributable to a direct pumping of protons ${ }^{3,4}$. It is possible that bicarbonate is a counter ion which accompanies hydrogen ion secretion. The data do not rule out the possibility that the primary event in cell elongation is indeed a lowering of the $p \mathrm{H}$ at the cell wall.

We thank the chemistry laboratory at the Pomona Valley Hospital for use of the microgasometer, and Drs J. Bonner, D. Rayle, R. Cleland and P. van Eikeren for discussion.

MARK SLOANe

D. SADAVA

Joint Science Department,

The Claremont Colleges,

Claremont, California 91711

Received May 1; accepted July 16, 1975.

1 Bonner, J., Protoplasma, 21, 406-423 (1934).

Hager, A., Henzel, H., and Krauss, A., Planta, Berl., 100, 47-75 (1971).

Rayle, D., Planta, Beri., 114, 63-73 (1973).

Cleland, R., Proc. natn. Acad. Sci. U.S.A., 70, 3092-3093 (1973)

Johnson, K., Daniels, D., Dowler, M., and Rayle, D., Pl. Physiol., Lancaster,

53, 224-228 (1974).
6 Marre, E., Lado, P., Caldogno, R., and Colombo, R., Pl. Sci. Lett., 1, 179-184 (1973).

7 Bonner, J., J. gen. Physiol., 17, 63-80 (1933)

8 Margolis, E. J., Chemical Principles of Ionic Equilibria (Macmillan, New York,

1966).
9 Evans, M., Ray, P. M., and Reinhold, L., Pl. Physiol., Lancaster, 47, 335-341 (1971). 10 Martin, J., and Juniper, B., The Cuticles of Plants (St Martin's Press, New York,
1970). 